\title{
Managing biodiversity using long-term regional data in the southeastern United States
}

\author{
THOMAS FosteR \\ University of West Georgia, Carrollton, USA; tfoster@westga.edu
}

\begin{abstract}
This article discusses how long-term regional data from historic documents, palynology and archeology are combined to inform decisions about biodiversity management in the southeastern United States.
\end{abstract}

The United States proactively manages federally owned lands with an objective to mitigate/limit the impacts of land-use activities on the long-term stability of the environment. For example, the United States Department of Defense (DoD) manages around 25 million acres of national military land. Impacts of military land use can include soil erosion, loss of endangered species, and degradation of habitats (Goran et al., 2002). Management involves planning and assessment that takes into consideration the types of environment to be managed and how they have changed over time, in order to maintain lands for training and operations. Fort Benning, founded in 1920, is a military base in Georgia and Alabama in the southeastern United States. It covers an area of $1052 \mathrm{~km}^{2}$ and is situated near the fall line of the Coastal Plain where soils consist of clay beds and sandy alluvial deposits (Fenneman, 1938). The pre-European (before ca. AD 1825) forest was primarily a pine-blackjack oak forest (Black et al., 2002). This article summarizes some recent research on long-term environmental changes and how it is being used to manage current ecological problems.

\section{Ecological Problems}

At Fort Benning, management challenges include protection of federally endangered Red Cockaded Woodpecker (Picoides borealis) and habitats important to rare species, such as the Gopher Tortoise (Gopherus polyphemus) and relict Trillium (Trillium reliquum) (Addington, 2004), as well as combating erosion (Fehmi et al., 2004). Proscribed forest fires have to be scheduled so as to maximize ideal training environments (e.g., reduced undergrowth) and preserve a forest composition that is conducive to species diversity and protects endangered species. Environmental managers at Fort Benning not only need to understand the long-term dynamics of the landscape but must also have the management tools for planning.

Therefore, as higlighted in a series of recent publications (Dale et al., 2002; Dale et al., 2004; Dale and Polasky, 2007; Foster, 2007; Foster et al., 2004; Foster and Cohen, 2007; Foster et al., 2010; Goran et

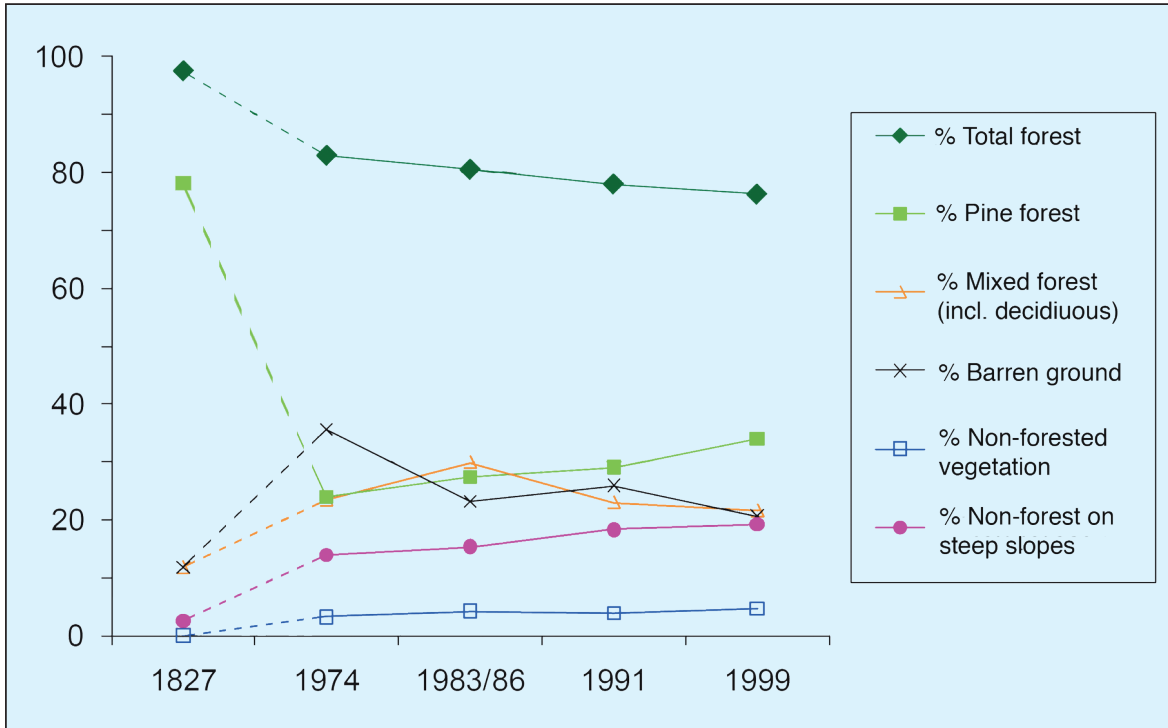

Figure 1: Graph showing the relative abundance of forest cover at Fort Benning, Georgia from 1827-1999 (adapted from Olsen et al., 2007). Data were collected from historic documents and satellite imagery.

al., 2002; Olsen et al., 2007), the DoD has funded research at Fort Benning focused on identifying long-term ecological metrics, human population settlement, and human activities that may have altered the environment.

\section{Data Sources}

Environmental management at Fort Benning has included the use of archeology, historic documents, historic and modern satellite images, and pollen from sediment cores. For example, historical "witness tree" records reveal pre-European settlement forest composition. Witness trees are boundary markers recorded on land survey maps that were created when lands were acquired by the state and federal government in the late $18^{\text {th }}$ to early $19^{\text {th }}$ century in Georgia and Alabama. The corner trees and four "witness trees" were recorded at the corners of each survey lot (approximately $82 \mathrm{ha}$ ), and the species of the trees were noted on maps and field notes. These data provide a record of the forest composition at the time that the $\mathrm{Na}$ tive Americans were removed by state and federal agencies in the early $19^{\text {th }}$ century and represent the pre-European forests and the forests under Native American management. These data were synthesized into a GIS and compared to historical satellite images (1974-1999; Fig. 1). Knowledge of human settlement and its inten- sity was revealed by systematic sampling of the military base with archeological investigation. The entire base was examined for human activity at 5 to $30 \mathrm{~m}$ intervals. The remains of human activity were analyzed for behavior type, intensity, population density, and economic activity. Lastly, long-term forest composition change was provided by analyzing pollen sequences from peat cores. Cores were dated with ${ }^{137} \mathrm{Cs} /{ }^{210} \mathrm{~Pb}$ and ${ }^{14} \mathrm{C}$ (Foster and Cohen, 2007).

\section{Findings}

As revealed through archeological investigations, Native Americans had lived in the Fort Benning region for at least 10,000 years though their management of the forest had changed dramatically in the last 1000 years (Foster, 2007; Kane and Keeton, 2000). European settlement and military activities within the last 100-200 years further affected the modern environment. Comparisons of the Native American managed forest to satellite imagery during the $20^{\text {th }}$ century indicates that the land cover at Fort Benning has changed significantly (Olsen et al., 2007). The prevailing trend is a decrease in pine and increase in deciduous forest (Fig. 1). Pine forest cover decreased from nearly $80 \%$ to below $40 \%$ from 1827 to 1999 . The increase in deciduous forest is mostly associated with riparian areas, as the riparian areas became 


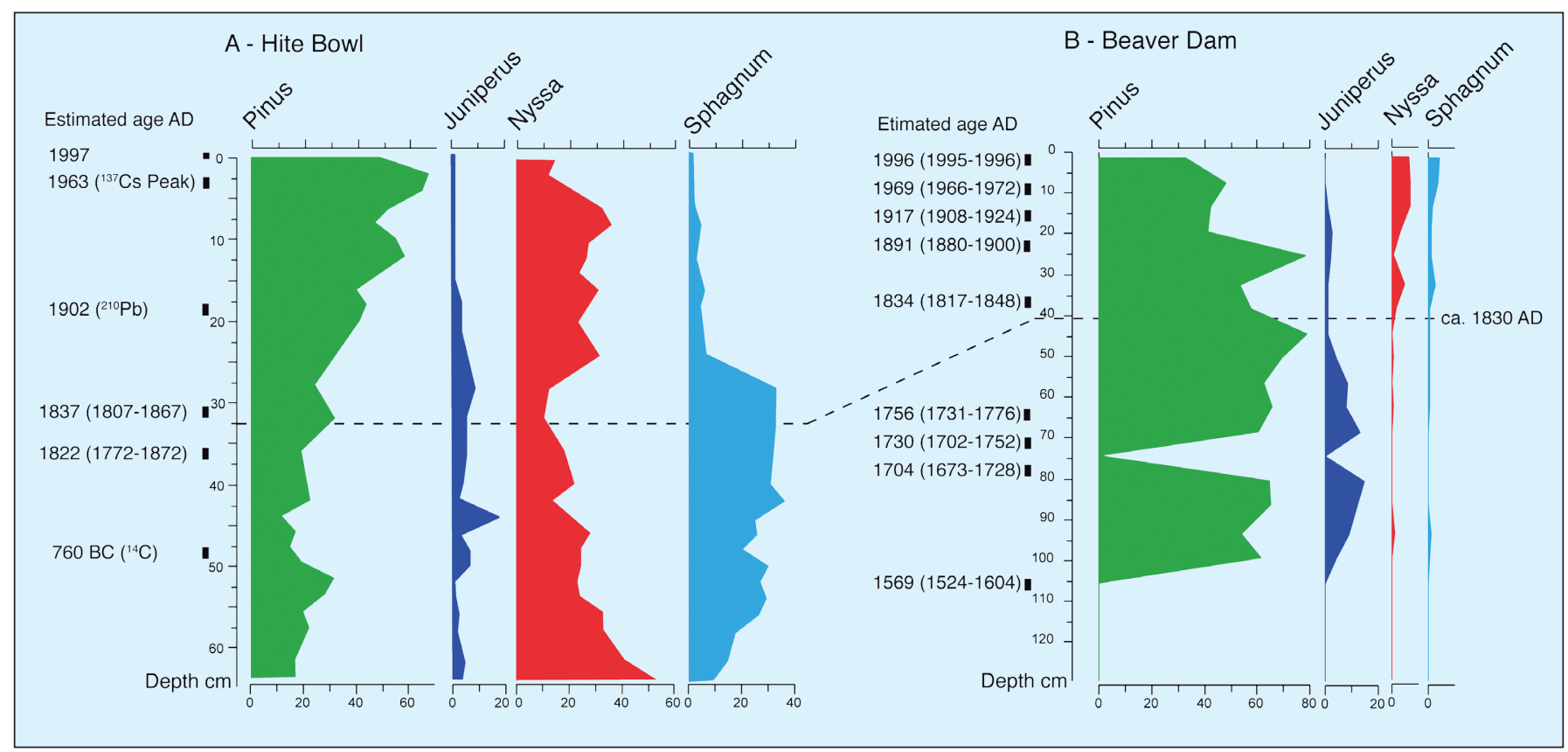

Figure 2: A) Pollen abundance from the Hite Bowl site, Fort Benning, Georgia (adapted from Foster and Cohen 2007). B) Same as A) for the Beaver Dam site. These two plots illustrate the localized effect of human activity on vegetation cover.

larger (Olsen et al., 2007). Forest cover was cut down soon after this area was settled by United States citizens, which resulted in increased soil erosion and habitat degradation (Foster and Cohen, 2007).

Analysis of pollen and charcoal from sediment cores revealed that change in forest composition was localized and affected by human activity. Figure 2 shows the significant changes in pollen composition since Native Americans were removed from the region around 1830. Pinus and Nyssa have increased in some localized areas whereas Sphagnum has decreased. The Native Americans had localized effects on pine and some hardwood species.

\section{Lessons for management}

Archeological data, in combination with analysis of pollen, charcoal and fungi from sediment cores (Foster and Cohen, 2007), indicate that the long term effects of human activity are highly localized. Sediment core data indicates that in areas where Native American settlement was dense, pine forest has increased dramatically since European and military settlement (Foster and Cohen, 2007). While in the areas where native people were less densely settled, pine forest has remained approximately the same (Fig. 2; Foster and Cohen, 2007).

Overall, the management plan at Fort Benning has prescribed intensive land use in some areas while preserving others. Based on comparisons of forest composition inside the base to that outside the base, this plan has increased the habitat for endangered species, such as the Red-
Cockaded Woodpecker (Picoides borealis), to a level that is higher than the regions outside of the military boundary (Olsen et al., 2007). Long-term data have also revealed the localized effects of management policies and are being used to design better policies that are sensitive to the range of biological diversity at Fort Benning.

The combination of long-term data on human settlement and economic activity combined with long-term ecological data reveal that the modern management of forest ecosystems is complicated and regionally variable. Though these data were recovered using diverse methods and varying units of investigation, they can be combined for regional analysis of long-term environmental change. Management decisions that cross ecological regions will likely include variable human activities and ecological conditions. In the case of Fort Benning, modern management has increased pine density beyond that created by pre-European settlement in one region and decreased pine density in another region beyond that of the preEuropean forests. An understanding of this process can only be gained through regional analysis of long-term environmental data combined with anthropological understanding of human activities. These data permit modern forest managers to understand the long-term effects of anthropogenic change and the interaction of those changes with the forest ecosystem. Such a long-term perspective is leading to better informed management practices.

\section{Data}

Data referenced in this article are available at http://semp.cecer.army.mil.

\section{References}

Black, B.A., Foster, H.T. II and Abrams, M.D., 2002: Combining environmentally dependent and independent analyses of witness tree data in east-central Alabama, Canadian Journal of Forest Research, 32: 2060-2075.

Dale, V.H., et al., 2004: Selecting a Suite of Ecological Indicators for Resource Management. In: L.A. Kapustka, H., et al. (Eds), Landscape Ecology and Wildife Habitat Evaluation: Critical Information for Ecological Risk Assessment, Land-Use Management Activities and Biodiversity Enhancement Practices, ASTM STP, ASTM International, 3-17

Foster, H.T. II, Black, B. and Abrams, M.D., 2004: A Witness Tree Analysis of the Effects of Native American Indians on the Pre-European Settlement Forests in East-Central Alabama, Human Ecology, 32(1): 27-47.

Foster, H.T. Ill and Cohen, A. 2007: Palynological evidence of the effects of the deerskin trade on eighteenth century forests of southeastern North America, American Antiquity, 72(1): 35-51.

Olsen, L.M., Dale, V.H. and Foster, H.T. II, 2007: Landscape Patterns as Indicators of Ecological Change at Fort Benning, Georgia, Landscape and Urban Planning, 79(2): 137-149.

For full references please consult:

http://www.pages-igbp.org/products/newsletters/ref2011_2.pdf 